NBER WORKING PAPER SERIES

NAMES, EXPECTATIONS AND THE BLACK-WHITE TEST SCORE GAP

David N. Figlio

Working Paper 11195

http://www.nber.org/papers/w11195

\author{
NATIONAL BUREAU OF ECONOMIC RESEARCH \\ 1050 Massachusetts Avenue \\ Cambridge, MA 02138 \\ March 2005
}

I am grateful to the Florida Department of Health and to an anonymous school district for the data used in this analysis, and to the National Science Foundation and National Institutes of Child Health and Human Development for financial support. I appreciate the comments of Jeff DeSimone, Kwabena Gymiah-Brempong, Larry Kenny, Darrin Lehman, Patrick Mason, Patrick McEwan, Kathleen Thomas and participants at the 2003 APPAM and SEA conferences and the NBER education program meeting, as well as seminar participants at Duke University, Florida State University, Stanford University, University of British Columbia, University of California-San Diego, Universite de Montreal, University of Florida, University of South Florida, and University of Toronto. All errors are my own. The views expressed herein are those of the author(s) and do not necessarily reflect the views of the National Bureau of Economic Research.

(C) 2005 by David N. Figlio. All rights reserved. Short sections of text, not to exceed two paragraphs, may be quoted without explicit permission provided that full credit, including $(\odot)$ notice, is given to the source. 
Names, Expectations and the Black-White Test Score Gap

David N. Figlio

NBER Working Paper No. 11195

March 2005

JEL No. I2

\begin{abstract}
This paper investigates the question of whether teachers treat children differentially on the basis of factors other than observed ability, and whether this differential treatment in turn translates into differences in student outcomes. I suggest that teachers may use a child's name as a signal of unobserved parental contributions to that child's education, and expect less from children with names that "sound" like they were given by uneducated parents. These names, empirically, are given most frequently by Blacks, but they are also given by White and Hispanic parents as well. I utilize a detailed dataset from a large Florida school district to directly test the hypothesis that teachers and school administrators expect less on average of children with names associated with low socioeconomic status, and these diminished expectations in turn lead to reduced student cognitive performance. Comparing pairs of siblings, I find that teachers tend to treat children differently depending on their names, and that these same patterns apparently translate into large differences in test scores.

David N. Figlio

Department of Economics

University of Florida

Gainesville, FL 32611-7140

and NBER

figlio@ufl.edu
\end{abstract}




\section{Names, Expectations and the Black-White Test Score Gap}

"Give your dog a bad name and it will be killed for you"

--Ghanaian proverb, as translated by Kwabena Gyimah-Brempong

Blacks and Whites differ dramatically along a wide range of outcomes, and education is no exception: The Black-White test gap exists at the beginning of school, and these gaps expand as children get older. There is no shortage of explanations for this pattern (Jencks and Phillips, 1998). In this paper I consider the role of teacher expectations in affecting the Black-White test score gap. Recent experimental evidence (Bertrand and Mullainathan, 2004) supports the notion that Blacks are differentially treated in the labor market, even by firms that advertise equal opportunity. I investigate whether teachers exhibit subtle biases as well. There is reason to believe that expectations matter: The recent work on teacher grading standards (Betts, 1995; Betts and Grogger, 2003; Figlio and Lucas, 2004) indicates that higher standards lead to improved student test scores.

The question of whether teachers treat Black and White children is not a new one. There exists considerable field evidence from social psychology conducted in the 1970s (e.g., Coates, 1972; Feldman and Orchowsky, 1979; Rubovitz and Maehr, 1973; Taylor, 1979) measuring differential perceptions of Black and White children. The consistent finding from this literature is that teachers take Black students less seriously than they do Whites (Ferguson, 1998). But there exist many questions regarding this field evidence: Are similar behaviors to the one-time laboratory encounters found in the classroom, with frequent interaction and feedback? And are results from the 1970s, in an era during which school racial integration was taking place, still relevant several decades later? 
This paper investigates the question of whether teachers treat children differentially on the basis of factors other than observed ability, and whether this differential treatment in turn translates into differences in student outcomes. Rather than look directly at whether teachers differentially treat Black and White children, I instead investigate whether teachers take cues from the names given to their students, and have systematically lower expectations for students with names that are associated more with low socio-economic status, names that are disproportionately given to Black children. I then relate these naming differences to test score differences.

The recent social psychology literature suggests that names affect both self-perception and others' perceptions of an individual. One line of this research (e.g., Pelham, Mirenberg and Jones, 2002) finds that individuals' names strongly affect their residential location choices, career choices and spousal selections. And these perceptions could influence outcomes: Ambady, Shih, Kim and Pittinsky (2001), among others, indicate that teachers' stereotypes, both positive and negative, influence children's cognitive performance. Jacobson and Rosenthal (1992) stress the importance of the self-fulfilling prophecy in the classroom.

One other paper in the economics literature (Fryer and Levitt, 2004) addresses the causal effects of names, and finds that Black women with racially-identifiable names tend to have similar outcomes to those with more racially-homogenized names. This result should not be contrasted with the work on names in the psychology literature; it may just 
be the case that racial identifiability per se of a name may not trigger changes in selfconcept or others' perceptions. I propose that the racially-identifiable names that may trigger differences in perceptions tend actually to be associated with low socio-economic status, rather than race per se. That is, I suggest that teachers may use a child's name as a signal of unobserved parental contributions to that child's education. In this vein, teachers may expect less from children with names that "sound" like they were given by uneducated parents. These names, empirically, are given most frequently by Blacks, but they are also given by White and Hispanic parents as well.

I utilize a detailed dataset from a large Florida school district to directly test the hypothesis that teachers and school administrators expect less on average of children with names associated with low socio-economic status, and these diminished expectations in turn lead to reduced student cognitive performance. In these data I observe student test scores as well as measures of teacher and school administrator expectations. Specifically, I observe whether the student is labeled as gifted and whether that student was promoted to the next grade level. While the gifted label has a specific diagnostic definition, schools and teachers have the flexibility to determine which students should be referred for potential placement into the gifted program, so expectations could still play an important role in this categorization. I use test score, gifted classification and transcript data for every student in this Florida school district from 1994-95 through 2000-01. Because of confidentiality restrictions, I cannot reveal the identity of the school district, but I can report that my dataset includes information on 55,046 children in 24,298 families with two or more children. 
Most notable about my dataset is that I can compare the outcomes of sibling pairs, as proxied by children sharing the same home address and phone number-and for a large subset of the dataset I can identify siblingship with certainty using parental names as well. I exploit variation within a family and school in the attributes of names, and directly compare how observationally-equivalent siblings with similar test scores but different types of names are treated differently by teachers. I find that teachers tend to treat children differently depending on their names, and that these same patterns apparently translate into large differences in test scores. These results are consistent with the notion that teachers and school administrators may subconsciously expect less of students with names associated with low socio-economic status-names that are disproportionately given to Black children--and these expectations may possibly become a self-fulfilling prophecy.

\section{What's in a Name?}

The premise of this paper is that teachers or other school administrators treat children who are observationally similar differently depending on their names. In order to address this question, I must first construct an agnostic index linking names to predicted socioeconomic status. I characterize a child's name using three different measures-a measure of the empirical prevalence of the name; an indicator of the "Blackness" of the name, a la Fryer and Levitt (2004); and an indicator of the socio-economic status of the name. This final measure is important because it allows one to distinguish between high- 
socio-economic status and low-socio-economic-status names, independent of racial associations with the name.

In order to measure the socio-economic status of a name, I use birth certificate data from all children born in Florida between 1989 and 1996 to predict the probability that a baby's mother will be a high school dropout. I decomposed every observed name into a series of phonemic components - combinations of sounds, letter orders, and punctuation, and then regressed these combinations against maternal dropout status to construct predictions of socio-economic status implied by a name. Four frequent attributes of low socio-economic status names are particularly striking: (1) the name begins with one of a number of prefixes, such as "lo-", "ta-", and "qua-“; (2) the name ends with one of a number of suffixes, such as "-isha" and "-ious"; (3) the name includes an apostrophe; and (4) the name has is particularly long, with several low-frequency consonants. The easiest way to characterize this fourth characteristic is to count the number of "Scrabble" points of the name-I consider a name to have a high Scrabble score if its Scrabble value exceeds twenty points.

Table 1 illustrates the attributes of families of children with the name attributes identified above. For the purposes of this table, I restrict the analysis to children with relatively uncommon names - those given to fewer than one in one thousand children; as a result, the table over-weights Black children, who account for 28 percent of live births in Florida but 45 percent of the children in the table. ${ }^{1}$ I find that as a name increases in its number

\footnotetext{
${ }^{1}$ In the regression results presented in the paper, the full set of children are included, regardless of name popularity. The purpose of this table is to show patterns among relatively unusual names.
} 
of identified attributes, its bearer is more likely to be born to a high school dropout mother, a teenaged mother, unmarried parents, and an impoverished family, and is more likely to be Black. Forty-one percent of children with no identified attributes are Black, while 98 percent of children with three or more attributes are Black. Thirty-two percent of mothers of children with no identified attributes are high school dropouts, as opposed to 55 percent of mothers with three or more attributes. Forty-seven percent of children with no identified attributes are born to single parents, while 94 percent of children with three or more attributes are born to single parents. "Black names"-names given more frequently to Blacks than to Whites-have demographics similar to those associated with one identified attribute—but this is driven primarily by the set of "Black names" that also have low socio-economic status attributes. Interestingly, "deviant" spellings of popular names, such as "Ashlee", share similar socio-economic status to those with no identified attributes, but are considerably less likely to be given to Black children.

This paper exploits within-family differences in the character of the names given to children. Therefore, it is necessary that there exist considerable variation in the attributes of names within a family. It is important to note from Table 1 that, while the majority of children with at least one low socio-economic-status name attribute are Black, 38 percent are not, and while Blacks are overwhelmingly disproportionately represented among the set of children with very low socio-economic-status names, Black children are still more likely to be given common names typically given to Whites. 
But do naming patterns vary within a family? Table 2 compares the names of successive siblings within the same family. Overall, if the first sibling in a pair has a name with at least one low-socio-economic status attribute, there is an 18 percent chance that the succeeding sibling will also have a name with at least one of these attributes. If the first sibling in a pair does not have a name with at least one of these attributes, there is a 12 percent chance that the next sibling will. Black families are more likely to give their children names with low socio-economic status connotations, but are not overwhelmingly so: Twenty-five percent of Black children who follow a sibling with at least one identified attribute also have a similar name, while 16 percent of Black children who follow a sibling with no identified attributes have a name identified as low socioeconomic status. Among Whites, 10 or 11 percent of next siblings have a measured low socio-economic status name, regardless of whether the first sibling had this type of name. Therefore, it appears as if there is considerable within-family variation in naming patterns. Moreover, in results not presented in this table, I find that families, both Black and White, are equally likely to transition from a low socio-economic status name to one that has no identified characteristics as they are to transition away from a name with no identified characteristics.

Table 2 also breaks down these same pattern by maternal education levels. While poorlyeducated Black women are the most likely to give their children names that I associate with low socio-economic status (indeed, the relationship between children's names and poor education is by construction!) one still observes that, in every combination of 
maternal education and race, there exists considerable within-family variation in the observed attributes of names.

Obviously, my measure of name socio-economic status is imperfect, and it only singles out 12 percent of all children as having low socio-economic status names. This is an advantage, however, if one's maintained assumption is that most names-even unique names--do not provide a strong signal about status, and that teachers (and others in the general population) form expectations about children in part based on how their names look and sound. I would expect that this is particularly important when it comes to very unusual names: Teachers may apply a mental "Frankfurter pornography test" when it comes to names, and "know it when they see it." While confidentiality restrictions prevent me from describing the names that are extremely uncommon in the Florida data set, I can identify names given at least ten times in the data to describe a hierarchy of names' expected socio-economic status, and present all regression results in terms of a range of observed names—first I compare two marginally common names, one given almost exclusively to White children ("Drew") and one given almost exclusively to Black children ("Dwayne"). ${ }^{2}$ Then I compare names along a hierarchy, from a name with one identified attribute ("Damarcus") to a name with two identified attributes ("Da'Quan") to a name with three or more identified attributes (none are observed with sufficient frequency to name here.) Almost no White children are given names with two or more observed attributes, but ten percent are given names with one of these attributes. Most are sufficiently uncommon to name here, but some names given to at least ten White

\footnotetext{
2 The names "Drew" and "Dwayne" are chosen because they are of virtually identical popularity among boys, but one name is given overwhelmingly to Whites and the other to Blacks.
} 
children in my dataset include "Jazzmyn" and "Chlo'e" (not to be confused with "Chloë", which is associated with high socio-economic status.)

Black families not only vary the attributes of the names that they give siblings, but they also tend to give their children substantially different middle names from first names. For instance, among Black children with first names with at least one identified attribute of low socio-economic status, 18 percent have middle names that also have at least one such attribute. Among Black children without any such attributes in their first names, 16 percent have middle names with at least one such attribute. White families give children middle names with at least one attribute of low socio-economic status about seven percent of the time, regardless of the attributes of the first name. Similar patterns are apparent for Black families with regard to racially-identifiable naming more generally: Among Black children with first names that are given at least three times as likely to White children as to Black children, these same children have middle names that share this attribute only 30 percent of the time, while they are nearly equally likely (27 percent) to have middle names that are given to at least three times as many Black children as White children. And while Black children who have names that are overwhelmingly given to Black children (at least 95 percent of the time) have similar middle names 45 percent of the time, they also receive names that are overwhelmingly White (given 25 or fewer percent of the time to Black children) 16 percent of the time. This widespread pattern of name-mixing for a given child indicates a general parental desire to impart cultural heritage on a child, while the widespread pattern of cross-sibling first name- 
mixing in the Black community suggests that for many Black families issues other than this desire for cultural heritage may prevail. ${ }^{3}$

\section{Measuring Expectations and Student Outcomes}

My measure of student outcomes is the student's national percentile ranking on a nationally-norm-referenced mathematics or reading examination such as the Stanford-8 or Iowa Test of Basic Skills (the precise test cannot be identified because it could identify the district) in grades three through nine. In the 2000-01 school year, the state of Florida instituted a statewide norm-referenced examination, the Stanford-9 examination.

Because I use national percentile rankings of each examination to measure test scores, scores should be comparable across years and tests. Another benefit of the national percentile ranking is that it is directly comparable across grade levels, a crucial point since my identification comes from pairs of siblings. My basic estimating equation is

$(\text { Test NPR })_{\text {ift }}=\alpha_{\mathrm{f}}+\beta(\text { Black name ratio })_{\mathrm{i}}+\delta(\text { Attribute index })_{\mathrm{i}}+\lambda(\text { Name frequency })_{\mathrm{i}}+$ $\gamma(\text { Birth order })_{i}+\eta(\text { Sex })_{i}+\theta(\text { Data from vital records })_{i}+\varepsilon_{\text {ift }}$,

for student $\mathrm{i}$ in family $\mathrm{f}$ at time t. The coefficients $\alpha$ represent family fixed effects. For all children born in Florida in 1989 or later, I also observe birth vital records—-data taken directly from the child's birth certificate. For these students, I control for birth weight, a measure of adequacy of prenatal care, an indicator for whether the mother had labor or delivery complications, maternal and paternal age and education, parental marital status, and an indicator for whether the father's information is known. For students born outside of Florida or before 1989, I include a flag representing missing birth vital records. Since

\footnotetext{
${ }^{3}$ Unfortunately, my data from the school district do not have middle names, so I am unable to measure whether students' middle names, which are generally not observed by teachers or school administrators, are associated with scholastic achievement or teacher expectations.
} 
the variables of interest, the Black name propensity and the name attribute index, does not vary for student i even though I typically observe more than one test score for each child, I adjust the standard errors to account for clustering at the student level. I limit the analysis to families in which all children in the same family are reported to have the same race or ethnicity.

Ferguson (1998) describes a number of ways in which researchers have measured teacher expectations toward Blacks and Whites in general. Typically, this research measures expectations and perceptions based on teacher reports on factors such as academic ability. In this paper, I measure teacher expectations empirically. I seek to have two separate measures of teacher expectations that typically move together, but where a prediction of low expectations would predict that they would move in opposite directions. Conditional on test scores, I suggest that teachers have low expectations for a student if at once (1) they are less likely to refer that student to the school's gifted program and (2) they are more likely to promote the student to the next grade. ${ }^{4}$ These two variables are very highly positively correlated, so a prediction that they would move in opposite directions is strong indeed. I therefore attempt to gauge whether teachers treat students with names associated with low socio-economic status differently by estimating:

$(\text { Grade promotion })_{\text {ift }}=\alpha_{\mathrm{f}}+\theta(\text { Math and reading test score NPR })_{\mathrm{ift}}+\beta(\text { Black name ratio })_{\mathrm{i}}$ $+\delta(\text { Attribute index })_{\mathrm{i}}+\lambda(\text { Name frequency })_{\mathrm{i}}+\gamma(\text { Birth order })_{\mathrm{i}}+\eta(\operatorname{Sex})_{\mathrm{i}}$

$$
+\mu(\text { Data from vital records })_{i}+\varepsilon_{\mathrm{ift}} \text {. }
$$

\footnotetext{
${ }^{4}$ In a previous version of this paper, I included a student's grades instead of promotion to the next grade. I characterize expectations using promotion because it is clearer and easier to interpret. However, the results presented herein are quite similar were I to replace promotion with student letter grades, conditional on test scores. These results are available upon request.
} 
I estimate these models with a linear probability specification. Conditional on observed test scores, an increased likelihood of grade promotion signifies lower academic standards. Therefore, if teachers have lower expectations of students with low socioeconomic status names, one would expect the coefficient on $\delta$ to be positive.

As mentioned above, I also measure teacher expectations by looking at a student's propensity to be referred to the school's gifted program. The procedures for identifying a student as gifted begin at the teacher level, where the teacher submits a subjective checklist of attributes of a gifted child. If teachers expect less of children with low socioeconomic status names, they may be less likely to refer them for further screening into the gifted program, all else equal. I therefore estimate variants of the preceding equation, using gifted placement as the dependent variable in place of the promotion variable. If teachers have lower expectations of students with low socio-economic status names, one would expect the coefficient on $\delta$ to be negative with respect to gifted placement. Given that the correlation between gifted placement and grade-point average is positive and strong, it is difficult to conceive of other stories besides teacher and school administrator expectations that could explain why a student would simultaneously be more likely to be promoted to the next grade while being less likely to be classified as gifted. For example, while pride of racial and ethnic identity may lead a student to achieve high grades in school, and therefore grade promotion, one would also expect that that child would be more, rather than less, likely to be considered gifted by teachers and school administrators. 
I estimate two variants of gifted status specifications. In one set of specifications, I do not control for lagged gifted status, while in a second specification I do. I carry out both specifications in an attempt to measure whether children's names influence the likelihood that a child will be enrolled in the gifted program at any given time, as well as whether names affect the year-to-year transitions into the gifted program. The results presented herein are the first set of specifications; however, the results are quite similar if instead the effect of names on gifted transitions is estimated. Those results are available on request.

\section{Results}

I characterize names along three dimensions: the "Blackness" of the name, the popularity of the name, and the index of a name's socio-economic status, based on name attributes. Table 3 presents estimates of the differential estimated effects of a child's name on reading and mathematics test scores, based on these three factors. In Table 3 I employ two different ways of measuring the socio-economic status of a name-either based on predicted maternal education levels (the left panel of results) or based on the number of low socio-economic status attributes (the right panel of results) of the name.

As Table 3 makes apparent, certain attributes of names concentrated in the Black community are related to diminished student test performance in mathematics and reading. But the results suggest that it is not the "Blackness" of the name per se that makes the difference: Holding constant family fixed effects, a boy with a name given almost exclusively to Black boys (such as "Dwayne") but with no identified low socio- 
economic status attributes is estimated to have two-thirds to three-quarters of a national percentile lower mathematics or reading scores than would a boy with a name observed with equal frequency but given almost exclusively to White boys (such as "Drew"). ${ }^{5}$ But all names with a high "Blackness" index are not created equal: A boy named "Damarcus" is estimated to have 1.1 national percentile points lower math and reading scores than would his brother named "Dwayne", all else equal, and "Damarcus" would in turn have three-quarters of a percentile ranking higher test scores than his brother named "Da'Quan". The upshot here is that while names associated with Black children tend to be associated with modestly lower test performance, the largest estimated negative relationships between names and test scores occur with regard to low socio-economic status. We observe virtually identical results regardless of whether I characterize names using a socio-economic status index or merely count the number of low socio-economic status attributes of the name. ${ }^{6}$

While a non-trivial fraction of the holders of identified low socio-economic status names are White, these names tend to be associated with minority students. Therefore, in the second panel of Table 3 I restrict the analysis to minority students only. I find results that are extremely similar to those reflecting the entire population. The estimated effect of receiving a "Black" name per se is somewhat higher with regard to mathematics and considerably lower with regard to reading, but the pattern persists that other attributes of

\footnotetext{
${ }^{5}$ I do not estimate name effects for specific names, but rather for name attributes, such as frequency of observation or fraction of the population with the given name who is Black. I identify name examples such as "Dwayne" and "Drew" simply to help fix ideas.

${ }^{6}$ An alternative approach to controlling for family fixed effects is to directly estimate a model of sibling differences. Here, and elsewhere in the paper, the results of a sibling difference model are very similar to those reported in the text of the paper.
} 
the name matter more than simply whether the name tends to be given more distinctly by Black families.

On the veracity of using within-family variation

Like most sibling-pair comparisons, this paper is subject to the criticism that external factors cause a family to assign names of different degrees of racial identifiability or exhibited socio-economic status to their children. For instance, a family could have undergone a substantial life change (e.g., different fathers for the pair of siblings) or could be becoming progressively assimilated or alienated from society in general. To the degree to which these alternate explanations hold water, they call into question whether the results described in this paper are causal.

While it is impossible to fully take into account these potential external factors, I can take steps to minimize the likelihood that these types of factors are driving my results. For instance, with regard to the potential change in parental combinations, I restrict the analysis to siblings who share the same father as a proxy (albeit an imperfect one) for family stability. For families for whom all students are observed in the birth vital records, I can measure this directly. For families where this is not the case, I measure students as having the same father if they share a last name and whose fathers have the same last name (I do not observe father's first name in my data). I further restrict the analysis to siblings born within two years of one another, in order to account for the fact that intact families still trend over time. 
I find results, reported in the third panel of Table 3, that are quite similar to those found in the overall population of siblings. For instance, the estimated effect of receiving a name of "Dwayne" vis-à-vis "Drew" is -0.52 percentile points (and not significant; compare to -0.68 points) in mathematics and -0.76 percentile points (also not significant, compare to -0.74 points) in reading. The estimated effect of receiving the name "Da'Quan" versus the name "Dwayne" (combining two columns) is -1.66 points (compare to -1.83 points) in mathematics and -2.46 points (compare to -1.95 points) in reading; both comparisons are strongly statistically significant. Therefore, at least to a first approximation, one can conclude that the sibling-pair comparisons described herein are not being fundamentally driven by dramatically changing families.

As an even stronger test, I next restrict the analysis to the pairs of twins in my data; these results are reported in the fourth panel of Table 3. Because the sample size is obviously considerably lower and quite low and the observable variation in names, regardless of race, is smaller than is seen among other sibling pairs (as families across the races tend to give their twins similar-sounding names) the standard errors are four to five times the size of those estimated using larger populations. But importantly, the signs of the estimated effects of name attributes remain as before, and the estimated effects are actually somewhat larger in the twins analysis than with the rest of the population. Indeed, the estimated effects are sufficiently larger in the reading specifications that these results remain statistically significant at conventional levels for reading. Among twins, low socioeconomic status names are associated with significantly lower reading scores and "Blacker" names per se are associated with lower mathematics scores. Therefore, even 
among twins, for whom there exists the least variation in family conditions and home life, children with different name attributes face different estimated outcomes.

\section{Estimated effects of names on teacher expectations measures}

In this paper I posit that a potential causal link between name attributes and low student performance comes via low levels of teacher expectations. As mentioned above, I seek to characterize teacher expectations using two variables that tend to trend together but that, when conditional on test scores, are predicted to move in opposite directions when capturing teacher expectations. Conditional on test scores, I measure teacher expectations by looking at whether a student is referred to the gifted program (thought of as high expectations) and whether a student is promoted to the next grade (thought of as low expectations.) A pattern of results that would be consistent with the test score results woud be to have lower socio-economic status names associated negatively with (conditional) gifted referral and positively with (conditional) grade promotion.

In Table 4 I investigate these relationships, restricting the analysis to the set of siblings born temporally near one another and sharing the same the same father, which is my preferred specification. ${ }^{7}$ One observes mixed evidence with regard to the "Blackness" of a name per se: Students given names associated more with Black families are more likely to be promoted, conditional on their test scores, than are their siblings with more homogenized names, but there is no relationship between the "Blackness" of a name per

\footnotetext{
${ }^{7}$ Just as the results for test scores are very similar between this specification and that drawn from the general population, so too are the results for teacher expectations measures. For instance, in the full population the estimated effect of being named "Damarcus" versus "Dwayne" is -0.17 in gifted (compare to -0.19 points in the table) and 0.015 for promotion (compare to 0.014 in the table.)
} 
se and conditional gifted status. But with regard to the measures of a names socioeconomic status, both sets of results are stronger, with "Damarcus" estimated to be 1.9 percentage points less likely to be referred to the gifted program than is his brother "Dwayne" with identical test scores, but at the same time he is 1.4 percentage points more likely to be promoted to the next grade than is "Dwayne." This pattern of results is consistent with a stronger relationship between test scores and a name's socio-economic status than with the "Blackness" of the name per se.

\section{Asian families as an alternative group}

Asian families also tend to mix children's names between racially-identifiable and more heterogeneous names. However, in the case of Asian families, I hypothesize that teachers and school administrators take children with more Asian-sounding names more seriously than they do Asian children who appear, by virtue of their names, to be more culturally assimilated, and therefore have higher expectations for Asian children with distinctively Asian names. One would expect, therefore, the exact opposite pattern of results with regard to Asian families as is observed with regard to "Black" names or low socioeconomic status names.

While I have many fewer name-mixing Asian families in my dataset than I have namemixing Black or White families, it is still possible to investigate within-family comparisons among Asian families. I observe strong evidence of differential expectations for Asian children with distinctively Asian names vis-à-vis Asian children with "Whiter" names. Specifically, I find that an Asian child with a name such as 
"Vivek" is more likely to be referred to the gifted program, conditional on test scores, and is more likely to have high mathematics test scores (for reading, the estimated result is positive still but statistically insignificant) than an Asian child with a name such as "Alex". I find no relationship between name and promotion status within Asian families, but this is due to the fact that there exists very little variation in promotion status within Asian families. In sum, therefore, there exists additional circumstantial evidence that teacher expectations may be influenced by student names and may in turn translate into student test scores.

\section{Do School Attributes Make a Difference?}

The results presented in Tables 3 and 4 are mean effects. But are the results uniform across school settings? Specifically, are teachers with more exposure to Black peers (or Black students) less likely to make assumptions about students' abilities and respond less to naming differences? Table 5 presents results of model specifications that address this question. In this table I estimate separate effects for schools with many Black teachers versus schools with few Black teachers; I choose the tenth and ninetieth percentiles of the distribution of the percentage of teachers who are Black to illustrate the patterns. ${ }^{8}$

I find that the racial breakdown of a school's teachers does not affect the relationships between the "Blackness" of a name per se and either student test scores or student gifted status, but it does influence the relationship between the "Blackness" of a name and the student's propensity to be promoted to the higher grade: Holding all else constant,

\footnotetext{
${ }^{8}$ The patterns are the same if I characterize schools on the basis of the racial composition of their student bodies.
} 
including test scores and family fixed effects, "Dwayne" is 1.8 percentage points more likely than his brother "Drew" to be promoted in a school with few Black teachers and is only 0.6 percentage points more likely to be promoted in a school with many Black teachers.

The patterns are more consistent with regard to a name's socio-economic status. "Damarcus", for instance, is estimated to have 1.2 percentile rankings lower math scores and 2.0 percentile rankings lower reading scores than his brother "Dwayne" in a $10^{\text {th }}$ percentile school, but in $90^{\text {th }}$ percentile schools there is no test score result at all. "Damarcus" is 2.5 percentage points less likely to be referred to the gifted program in a school with few Black teachers than is his brother "Drew", but the difference is one-tenth that size and statistically insignificant in schools with many Black teachers. And "Damarcus" is 1.6 percentage points more likely to be promoted in a school with few Black teachers than is his brother "Drew", an estimated effect twice the size as seen in schools with many Black teachers. These results are consistent with an "exposure" story, in which schools with many Black teachers tend to assign less weight to children's names than do schools where few faculty members are Black.

\section{Conclusions}

The persistence of the Black-White test score gap, and its widening over the course of the school cycle, is an issue of significant public policy concern. This paper presents evidence that a portion of these patterns could be due to the names given particularly prevalently to Black children. Children with names associated with low socio-economic 
status, and to a limited degree, with "Blackness" per se, tend to score lower on their reading and mathematics tests, relative to their siblings with less race or class-identifiable names. That "Blackness" per se apparently matters considerably less than does the perceives socio-economic status of a name is consistent with the findings of Fryer and Levitt (2004) in a different context.

I suggest that the mechanism through which this pattern comes about involves the expectations of teachers and school administrators regarding children with race or classidentifiable names. Children with names that are associated with low socio-economic status are estimated to be promoted at higher rates than are like-scoring children with less identifiable names, but they are also less likely to be called gifted. This pattern of results is consistent with a story of low teacher expectations for students with names associated with low socio-economic status.

The estimated relationship between names and test scores suggests that a reasonably large fraction of the Black-White test score gap can be explained by children's naming patterns. Because Black children are considerably more likely to be given names associated with low socio-economic status than are White children, one can calculate that around 15 percent of the Black-White test score gap may be due to differences in names given across the races. Since my characterization of low socio-economic status names is measured with error, the actual share of the test score gap that can be explained by naming patterns may be still larger. Naming patterns can also help to explain the widening of the test score gap over time: Since Black families and White families are 
increasingly diverging in the socio-economic status of the names that they give their children, this could manifest itself in a widening test score gap as well.

The hypothesis that teacher expectations are responsible for these results is bolstered by the evidence that my results are stronger in cases in which teachers have fewer Black colleagues (or are less likely to be Black themselves) or have less exposure to Black students than in cases where exposure is greater. The negative estimated effects of low socio-economic status naming on test scores, as well as evidence of differential teacher expectations, are smaller in schools with large numbers of Black teachers or students than in schools with few Black teachers or students. It follows that in schools with larger numbers of Black students and teachers, teachers perhaps form fewer preconceived notions about children purely on the basis of their names, and do not adjust their expectations based on names as much as they may in schools where contact with Black students and peers is more limited.

This hypothesis is also bolstered by the finding that the opposite set of results are observed in the instance of Asian families, for whom a racially-identifiable name may signal attributes that are perceived to be associated with success. Asian children with racially-identifiable names apparently face higher teacher expectations and also tend to score higher on examinations.

Bertrand and Mullainathan (2004) report evidence of racial discrimination even in firms that claim to take active non-discriminatory steps. I suspect that a similar phenomenon 
occurs in education, as my findings indicate that teachers treat students within a race, and even within a family, differently. This finding suggests a role for professional development and teacher training; if teachers are more sensitive to the apparent tendency to treat Black students differently based on their names, they may respond accordingly. 


\section{References}

Ambady, Nalini, Margaret Shih, Amy Kim and Todd Pittinsky, "Stereotype

Susceptibility in Children: Effects of Identity Activation on Quantitative Performance," Psychological Science, 2001.

Bertrand, Marianne and Sendhil Mullainathan, "Are Emily and Greg More Employable than Lakisha and Jamal? A Field Experiment on Labor Market Discrimination," American Economic Review, 2004.

Betts, Julian and Jeff Grogger, "The Effects of Grading Standards on Student Achievement, Educational Attainment, and Entry-Level Earnings," Economics of Education Review, 2003.

Coates, Brian, "White Adult Behavior Toward Black and White Children," Child Development, 1972.

Feldman, Robert and Stanley Orchowsky, "Race and Performance of Students as Determinants of Teacher Nonverbal Behavior," Contemporary Educational Psychology, 1979.

Ferguson, Ronald, "Teachers' Expectations and the Test Score Gap," in C. Jencks and M. Phillips, eds., The Black-White Test Score Gap,' Washington, DC: Brookings Institution Press, 1998.

Figlio, David and Maurice Lucas, "Do Higher Grading Standards Affect Student Performance?" Journal of Public Economics, 2004.

Fryer, Roland and Steven Levitt, "The Causes and Consequences of Distinctively Black Names," Quarterly Journal of Economics, 2004.

Jencks, Christopher and Meredith Phillips, The Black-White Test Score Gap, Washington, DC: Brookings Institution Press, 1998.

Lillard, Dean and Phillip DeCicca, "Higher Standards, More Dropouts? Evidence Within and Across Time," Economics of Education Review, 2001.

Pelham, Brett, Matthew Mirenberg and John Jones, "Why Susie Sells Seashells by the Seashore: Implicit Egotism and Major Life Decisions," Journal of Personality and Social Psychology, 2002.

Jacobson, Lenore and Robert Rosenthal, Pygmalion in the Classroom, New York: Irvington, 1992.

Rubovits, Pamela and Martin Maehr, "Pygmalion Black and White," Journal of Personality and Social Psychology, 1973. 
Taylor, Marylee, "Race, Sex, and the Expression of Self-Fulfilling Prophecies in a Laboratory Teaching Situation," Personality and Social Psychology, 1979. 
Table 1: Attributes of Families Giving Children Low-Socio-Economic Status Names (Among Children With Uncommon Names)

\begin{tabular}{|l|l|l|l|l|l|}
\hline \multirow{2}{*}{$\begin{array}{l}\text { Name } \\
\text { attribute }\end{array}$} & \begin{tabular}{l} 
Fraction of children with name attributes who: \\
\cline { 2 - 6 } \\
a mother \\
who is a \\
high school \\
dropout
\end{tabular} & $\begin{array}{l}\text { Are in } \\
\text { poverty at } \\
\text { the time of } \\
\text { birth }\end{array}$ & $\begin{array}{l}\text { Have } \\
\text { married } \\
\text { parents at } \\
\text { the time of } \\
\text { birth }\end{array}$ & $\begin{array}{l}\text { Are born to } \\
\text { a teenaged } \\
\text { mother }\end{array}$ & Are Black \\
\hline $\begin{array}{l}\text { Name has no } \\
\text { attributes of } \\
\text { low socio- } \\
\text { economic } \\
\text { status }\end{array}$ & 0.32 & 0.57 & 0.53 & 0.19 & 0.41 \\
\hline $\begin{array}{l}\text { Name has } \\
\text { low SES } \\
\text { attribute }\end{array}$ & 0.38 & 0.68 & 0.37 & 0.28 & 0.62 \\
\hline $\begin{array}{l}\text { Name has 2 } \\
\text { low SES } \\
\text { attributes }\end{array}$ & 0.49 & 0.86 & 0.14 & 0.42 & 0.96 \\
\hline $\begin{array}{l}\text { Name has } \\
\text { 3+ low SES } \\
\text { attributes }\end{array}$ & 0.55 & 0.90 & 0.06 & 0.52 & 0.90 \\
\hline $\begin{array}{l}\text { Name is } \\
\text { given } \\
\text { primarily to } \\
\text { Blacks }\end{array}$ & 0.41 & 0.76 & 0.27 & 0.30 & 0.26 \\
\hline $\begin{array}{l}\text { Name has a } \\
\text { "deviant" } \\
\text { spelling of a } \\
\text { common } \\
\text { name }\end{array}$ & 0.32 & 0.53 & & 0.59 & \\
\hline
\end{tabular}

Notes: Data come from Florida birth vital records from 1989 through 1996. To be counted in the analysis for the purposes of this table, a name must be given to fewer than one in one thousand children. "Low-SES attributes" were determined based on regressions of maternal education on name attributes and are as follows: (1) name has a prefix associated with low socio-economic status, such as "lo-", "ta-", or "qua-"; (2) name has a suffix associated with low socio-economic status, such as "-ious" or "-isha"; (3) name has an apostrophe; and (4) name has a combination of length and low-frequency consonants (measured as 20 or more Scrabble points). 
Table 2: Within-Family Transitions in Naming Attributes:

Within Sibling Pairs: Probability that the Second Sibling Has One or More Low SocioEconomic Status Name Attribute

\begin{tabular}{|c|c|c|c|}
\hline & All families & Black families & White families \\
\hline $\begin{array}{l}\text { First child has no } \\
\text { low-SES name } \\
\text { attributes }\end{array}$ & 0.12 & 0.16 & 0.10 \\
\hline $\begin{array}{l}\text { First child has 1+ } \\
\text { low-SES name } \\
\text { attribute }\end{array}$ & 0.18 & 0.25 & 0.11 \\
\hline \multicolumn{4}{|c|}{ Families with high school dropout mothers } \\
\hline $\begin{array}{l}\text { First child has no } \\
\text { low-SES name } \\
\text { attributes }\end{array}$ & 0.12 & 0.17 & 0.10 \\
\hline $\begin{array}{l}\text { First child has 1+ } \\
\text { low-SES name } \\
\text { attribute }\end{array}$ & 0.19 & 0.26 & 0.11 \\
\hline \multicolumn{4}{|c|}{ Families with high school graduate mothers } \\
\hline $\begin{array}{l}\text { First child has no } \\
\text { low-SES name } \\
\text { attributes }\end{array}$ & 0.11 & 0.15 & 0.10 \\
\hline $\begin{array}{l}\text { First child has 1+ } \\
\text { low-SES name } \\
\text { attribute }\end{array}$ & 0.17 & 0.25 & 0.11 \\
\hline
\end{tabular}

Notes: Data come from Florida birth vital records from 1989 through 1996. "Low-SES attributes" were determined based on regressions of maternal education on name attributes and are as follows: (1) name has a prefix associated with low socio-economic status, such as "lo-", "ta-", or "qua-"; (2) name has a suffix associated with low socio-economic status, such as "-ious" or "-isha"; (3) name has an apostrophe; and (4) name has a combination of length and lowfrequency consonants (measured as 20 or more Scrabble points). Siblings are matched based on material social security number. 
Table 3: Name Attributes and Student Test Scores

Estimated Relationship Between Changing Names and Student Test Scores Within-Family Comparisons

\begin{tabular}{|c|c|c|c|c|c|c|c|}
\hline & \multicolumn{4}{|c|}{$\begin{array}{l}\text { Estimated effect of changing names, } \\
\text { based on index of predicted socio-economic } \\
\text { status of name }\end{array}$} & \multicolumn{3}{|c|}{$\begin{array}{l}\text { Estimated effect of changing names, } \\
\text { based on the number of low-SES } \\
\text { attributes of the name }\end{array}$} \\
\hline & $\begin{array}{l}\text { Dwayne vs. } \\
\text { Drew }\end{array}$ & $\begin{array}{l}\text { Damarcus } \\
\text { vs. } \\
\text { Dwayne }\end{array}$ & $\begin{array}{l}\text { Da'Quan } \\
\text { vs. } \\
\text { Damarcus }\end{array}$ & $\begin{array}{l}\text { Lowest } \\
\text { predicted } \\
\text { SES vs. } \\
\text { Da'Quan }\end{array}$ & $\begin{array}{l}\text { Dwayne vs. } \\
\text { Drew }\end{array}$ & $\begin{array}{l}\text { Damarcus } \\
\text { vs. } \\
\text { Dwayne }\end{array}$ & $\begin{array}{l}\text { Da'Quan } \\
\text { vs. } \\
\text { Damarcus }\end{array}$ \\
\hline $\begin{array}{l}\text { Factors } \\
\text { changing }\end{array}$ & $\begin{array}{l}\text { "Blackness" } \\
\text { of name }\end{array}$ & $\begin{array}{l}\text { SES, } \\
\text { frequency } \\
\text { of name } \\
\end{array}$ & $\begin{array}{l}\text { SES of } \\
\text { name }\end{array}$ & $\begin{array}{l}\text { SES of } \\
\text { name }\end{array}$ & $\begin{array}{l}\text { "Blackness" } \\
\text { of name }\end{array}$ & $\begin{array}{l}\text { SES, } \\
\text { frequency } \\
\text { of name }\end{array}$ & $\begin{array}{l}\text { SES of } \\
\text { name }\end{array}$ \\
\hline Math & $\begin{array}{l}-0.684 \\
(0.486)\end{array}$ & $\begin{array}{l}-1.104 \\
(0.411)\end{array}$ & $\begin{array}{l}-0.731 \\
(0.283)\end{array}$ & $\begin{array}{l}-0.655 \\
(0.254)\end{array}$ & $\begin{array}{l}-0.672 \\
(0.486)\end{array}$ & $\begin{array}{l}-0.832 \\
(0.332)\end{array}$ & $\begin{array}{l}-0.787 \\
(0.332)\end{array}$ \\
\hline Reading & $\begin{array}{l}-0.741 \\
(0.425)\end{array}$ & $\begin{array}{l}-1.174 \\
(0.371) \\
\end{array}$ & $\begin{array}{l}-0.782 \\
(0.256)\end{array}$ & $\begin{array}{l}-0.702 \\
(0.229)\end{array}$ & $\begin{array}{l}-0.725 \\
(0.425)\end{array}$ & $\begin{array}{l}-0.903 \\
(0.298)\end{array}$ & $\begin{array}{l}-0.864 \\
(0.297)\end{array}$ \\
\hline \multicolumn{8}{|c|}{ MINORITY STUDENTS ONLY } \\
\hline Math & $\begin{array}{l}-1.006 \\
(0.609)\end{array}$ & $\begin{array}{l}-1.178 \\
(0.670)\end{array}$ & $\begin{array}{l}-0.760 \\
(0.462)\end{array}$ & $\begin{array}{l}-0.681 \\
(0.414)\end{array}$ & $\begin{array}{l}-1.004 \\
(0.609)\end{array}$ & $\begin{array}{l}-0.845 \\
(0.520)\end{array}$ & $\begin{array}{l}-0.769 \\
(0.520)\end{array}$ \\
\hline Reading & $\begin{array}{l}-0.282 \\
(0.525)\end{array}$ & $\begin{array}{l}-1.079 \\
(0.574)\end{array}$ & $\begin{array}{l}-0.712 \\
(0.395)\end{array}$ & $\begin{array}{l}-0.639 \\
(0.354)\end{array}$ & $\begin{array}{l}-0.269 \\
(0.526)\end{array}$ & $\begin{array}{l}-0.825 \\
(0.443)\end{array}$ & $\begin{array}{l}-0.779 \\
(0.443)\end{array}$ \\
\hline \multicolumn{8}{|c|}{ CHILDREN BORN TO SAME FATHER WITHIN TWO YEARS OF ONE ANOTHER } \\
\hline Math & $\begin{array}{l}-0.520 \\
(0.588)\end{array}$ & $\begin{array}{l}-1.000 \\
(0.492) \\
\end{array}$ & $\begin{array}{l}-0.664 \\
(0.340) \\
\end{array}$ & $\begin{array}{l}-0.595 \\
(0.304) \\
\end{array}$ & $\begin{array}{l}-0.507 \\
(0.589) \\
\end{array}$ & $\begin{array}{l}-0.760 \\
(0.396) \\
\end{array}$ & $\begin{array}{l}-0.723 \\
(0.396) \\
\end{array}$ \\
\hline Reading & $\begin{array}{l}-0.761 \\
(0.512) \\
\end{array}$ & $\begin{array}{l}-1.472 \\
(0.447) \\
\end{array}$ & $\begin{array}{l}-0.986 \\
(0.308) \\
\end{array}$ & $\begin{array}{l}-0.884 \\
(0.276)\end{array}$ & $\begin{array}{l}-0.735 \\
(0.512) \\
\end{array}$ & $\begin{array}{l}-1.150 \\
(0.358) \\
\end{array}$ & $\begin{array}{l}-1.107 \\
(0.357) \\
\end{array}$ \\
\hline \multicolumn{8}{|l|}{ TWINS } \\
\hline Math & $\begin{array}{l}-4.105 \\
(2.736)\end{array}$ & $\begin{array}{l}-1.772 \\
(1.995) \\
\end{array}$ & $\begin{array}{l}-1.200 \\
(1.377) \\
\end{array}$ & $\begin{array}{l}-1.075 \\
(1.235)\end{array}$ & $\begin{array}{l}-4.123 \\
(2.736)\end{array}$ & $\begin{array}{l}-1.612 \\
(1.622)\end{array}$ & $\begin{array}{l}-1.577 \\
(1.620) \\
\end{array}$ \\
\hline Reading & $\begin{array}{l}-1.814 \\
(2.702)\end{array}$ & $\begin{array}{l}-3.462 \\
(1.910)\end{array}$ & $\begin{array}{l}-2.403 \\
(1.315)\end{array}$ & $\begin{array}{l}-2.155 \\
(1.179)\end{array}$ & $\begin{array}{l}-1.834 \\
(2.703)\end{array}$ & $\begin{array}{l}-2.815 \\
(1.555)\end{array}$ & $\begin{array}{l}-2.833 \\
(1.547)\end{array}$ \\
\hline
\end{tabular}

Notes: Clustered standard errors are in parentheses beneath estimated name effects. The estimates reported above are based on the coefficient estimates on name frequency, "Black name index" (computed by observing the proportion of time in which the specific name is given to a Black child), and an indicator of the socio-economic status of the name-either based on maternal education (left four columns) or the number of low socio-economic status attributes (right three columns). Dwayne and Drew are observed with about the same frequency in the data, but Drew is almost exclusively White, while Dwayne is almost exclusively Black. Damarcus has one low-SES attribute and is also less prevalently observed in the data. Da' Quan is observed with the same approximate frequency as Damarcus but has two low-SES attributes. I cannot name the names with the lowest-predicted SES because they are all unique names. All regressions include family fixed effects, grade fixed effects, and year fixed effects. Regressions also include controls for sex, birth order, birth weight, adequacy of prenatal care, complications of labor and delivery, parental education, maternal age, and parental marital status at birth. 
Table 4: Name Attributes and Teacher Expectations Measures

Estimated Relationship Between Changing Names and Teacher Expectations

Within-Family Comparisons, Children Born to Same Father Within Two Years

\begin{tabular}{|l|l|l|l|l|l|l|l|}
\hline & \multicolumn{3}{|l|}{$\begin{array}{l}\text { Estimated effect of changing names, } \\
\text { based on index of predicted socio-economic } \\
\text { status of name }\end{array}$} & \multicolumn{2}{l|}{$\begin{array}{l}\text { Estimated effect of changing names, } \\
\text { based on the number of low-SES } \\
\text { attributes of the name }\end{array}$} \\
\hline $\begin{array}{l}\text { Dwayne vs. } \\
\text { Drew }\end{array}$ & $\begin{array}{l}\text { Damarcus } \\
\text { vs. } \\
\text { Dwayne }\end{array}$ & $\begin{array}{l}\text { Da'Quan } \\
\text { vs. } \\
\text { Damarcus }\end{array}$ & $\begin{array}{l}\text { Lowest } \\
\text { predicted } \\
\text { SES vs. } \\
\text { Da'Quan }\end{array}$ & $\begin{array}{l}\text { Dwayne vs. } \\
\text { Drew }\end{array}$ & $\begin{array}{l}\text { Damarcus } \\
\text { vs. } \\
\text { Dwayne }\end{array}$ & $\begin{array}{l}\text { Da'Quan } \\
\text { vs. } \\
\text { Damarcus }\end{array}$ \\
\hline $\begin{array}{l}\text { Factors } \\
\text { changing }\end{array}$ & $\begin{array}{l}\text { "Blackness" } \\
\text { of name }\end{array}$ & $\begin{array}{l}\text { SES, } \\
\text { frequency } \\
\text { of name }\end{array}$ & $\begin{array}{l}\text { SES of } \\
\text { name }\end{array}$ & $\begin{array}{l}\text { SES of } \\
\text { name }\end{array}$ & $\begin{array}{l}\text { "Blackness" } \\
\text { of name }\end{array}$ & $\begin{array}{l}\text { SES, } \\
\text { frequency } \\
\text { of name }\end{array}$ & $\begin{array}{l}\text { SES of } \\
\text { name }\end{array}$ \\
\hline $\begin{array}{l}\text { Student } \\
\text { referred } \\
\text { to gifted } \\
\text { program }\end{array}$ & $\begin{array}{l}0.005 \\
(0.007)\end{array}$ & $\begin{array}{l}-0.019 \\
(0.008)\end{array}$ & $\begin{array}{l}-0.013 \\
(0.005)\end{array}$ & $\begin{array}{l}-0.012 \\
(0.005)\end{array}$ & $\begin{array}{l}0.005 \\
(0.007)\end{array}$ & $\begin{array}{l}-0.015 \\
(0.006)\end{array}$ & $\begin{array}{l}-0.015 \\
(0.006)\end{array}$ \\
\hline $\begin{array}{l}\text { Student } \\
\text { promoted } \\
\text { to higher } \\
\text { grade }\end{array}$ & $\begin{array}{l}0.011 \\
(0.006)\end{array}$ & $\begin{array}{l}0.014 \\
(0.006)\end{array}$ & $\begin{array}{l}0.010 \\
(0.004)\end{array}$ & $\begin{array}{l}0.009 \\
(0.004)\end{array}$ & $\begin{array}{l}0.010 \\
(0.006)\end{array}$ & $\begin{array}{l}0.014 \\
(0.005)\end{array}$ & $\begin{array}{l}0.013 \\
(0.005)\end{array}$ \\
\hline
\end{tabular}

Notes: Clustered standard errors are in parentheses beneath estimated name effects. The estimates reported above are based on the coefficient estimates on name frequency, "Black name index" (computed by observing the proportion of time in which the specific name is given to a Black child), and an indicator of the socio-economic status of the name-either based on maternal education (left four columns) or the number of low socio-economic status attributes (right three columns). Dwayne and Drew are observed with about the same frequency in the data, but Drew is almost exclusively White, while Dwayne is almost exclusively Black. Damarcus has one low-SES attribute and is also less prevalently observed in the data. Da' Quan is observed with the same approximate frequency as Damarcus but has two low-SES attributes. I cannot name the names with the lowest-predicted SES because they are all unique names. All regressions include family fixed effects, grade fixed effects, and year fixed effects. Regressions also include controls for sex, birth order, birth weight, adequacy of prenatal care, complications of labor and delivery, parental education, maternal age, and parental marital status at birth. All regressions include controls for reading and mathematics test scores in the year that the gifted referral or promotion decision was made. 
Table 5: Differential Teacher Expectations, by School Type

Estimated Relationship Between Changing Names and Teacher Expectations, By Fraction Black Teachers in the School

\begin{tabular}{|c|c|c|c|c|c|c|c|c|}
\hline & \multicolumn{2}{|c|}{ Dwayne vs. Drew } & \multicolumn{2}{|c|}{$\begin{array}{l}\text { Damarcus vs. } \\
\text { Dwayne }\end{array}$} & \multicolumn{2}{|c|}{$\begin{array}{l}\text { Da'Quan vs. } \\
\text { Damarcus }\end{array}$} & \multicolumn{2}{|c|}{$\begin{array}{l}\text { Lowest predicted } \\
\text { SES vs. Da'Quan }\end{array}$} \\
\hline & $\begin{array}{l}10^{\text {th }} \\
\text { percentile } \\
\% \text { black } \\
\text { teachers }\end{array}$ & $\begin{array}{l}90^{\text {th }} \\
\text { percentile } \\
\text { \%black } \\
\text { teachers }\end{array}$ & $\begin{array}{l}10^{\text {th }} \\
\text { percentile } \\
\% \text { black } \\
\text { teachers }\end{array}$ & $\begin{array}{l}90^{\text {th }} \\
\text { percentile } \\
\% \text { black } \\
\text { teachers }\end{array}$ & $\begin{array}{l}10^{\text {th }} \\
\text { percentile } \\
\% \text { black } \\
\text { teachers }\end{array}$ & $\begin{array}{l}90^{\text {th }} \\
\text { percentile } \\
\text { \%black } \\
\text { teachers }\end{array}$ & $\begin{array}{l}10^{\text {th }} \\
\text { percentile } \\
\text { \%black } \\
\text { teachers }\end{array}$ & $\begin{array}{l}90^{\text {th }} \\
\text { percentile } \\
\% \text { black } \\
\text { teachers }\end{array}$ \\
\hline Math test & $\begin{array}{l}-0.508 \\
(0.650) \\
\end{array}$ & $\begin{array}{l}-0.847 \\
(0.957) \\
\end{array}$ & $\begin{array}{l}-1.207 \\
(0.556) \\
\end{array}$ & $\begin{array}{l}-0.285 \\
(1.095)\end{array}$ & $\begin{array}{l}-0.804 \\
(0.384) \\
\end{array}$ & $\begin{array}{l}-0.192 \\
(0.753) \\
\end{array}$ & $\begin{array}{l}-0.721 \\
(0.344) \\
\end{array}$ & $\begin{array}{l}-0.172 \\
(0.675) \\
\end{array}$ \\
\hline Reading test & $\begin{array}{l}-1.077 \\
(0.579)\end{array}$ & $\begin{array}{l}-0.602 \\
(0.802)\end{array}$ & $\begin{array}{l}-2.026 \\
(0.513)\end{array}$ & $\begin{array}{c}0.283 \\
(0.952)\end{array}$ & $\begin{array}{l}-1.355 \\
(0.354)\end{array}$ & $\begin{array}{c}0.199 \\
(0.654)\end{array}$ & $\begin{array}{l}-1.215 \\
(0.317)\end{array}$ & $\begin{array}{c}0.178 \\
(0.586)\end{array}$ \\
\hline $\begin{array}{l}\text { Student } \\
\text { referred to } \\
\text { gifted } \\
\text { program }\end{array}$ & $\begin{array}{c}0.006 \\
(0.009)\end{array}$ & $\begin{array}{c}0.005 \\
(0.014)\end{array}$ & $\begin{array}{l}-0.025 \\
(0.009)\end{array}$ & $\begin{array}{l}-0.002 \\
(0.014)\end{array}$ & $\begin{array}{l}-0.017 \\
(0.006)\end{array}$ & $\begin{array}{l}-0.001 \\
(0.010)\end{array}$ & $\begin{array}{l}-0.015 \\
(0.006)\end{array}$ & $\begin{array}{l}-0.001 \\
(0.009)\end{array}$ \\
\hline $\begin{array}{l}\text { Student } \\
\text { promoted to } \\
\text { higher grade }\end{array}$ & $\begin{array}{l}0.018 \\
(0.007)\end{array}$ & $\begin{array}{c}0.006 \\
(0.011)\end{array}$ & $\begin{array}{l}0.016 \\
(0.007)\end{array}$ & $\begin{array}{c}0.009 \\
(0.013)\end{array}$ & $\begin{array}{c}0.011 \\
(0.005)\end{array}$ & $\begin{array}{c}0.006 \\
(0.009)\end{array}$ & $\begin{array}{l}0.010 \\
(0.004)\end{array}$ & $\begin{array}{c}0.005 \\
(0.008)\end{array}$ \\
\hline
\end{tabular}

Notes: Clustered standard errors are in parentheses beneath estimated name effects. The estimates reported above are based on the coefficient estimates on name frequency, "Black name index" (computed by observing the proportion of time in which the specific name is given to a Black child), and an indicator of the socio-economic status of the name based on maternal education. Schools are stratified based on the fraction of teachers in the school who are Black. Dwayne and Drew are observed with about the same frequency in the data, but Drew is almost exclusively White, while Dwayne is almost exclusively Black. Damarcus has one low-SES attribute and is also less prevalently observed in the data. Da' Quan is observed with the same approximate frequency as Damarcus but has two low-SES attributes. I cannot name the names with the lowest-predicted SES because they are all unique names. All regressions include family fixed effects, grade fixed effects, and year fixed effects. Regressions also include controls for sex, birth order, birth weight, adequacy of prenatal care, complications of labor and delivery, parental education, maternal age, and parental marital status at birth. Student gifted referral and promotion regressions include controls for reading and mathematics test scores in the year that the gifted referral or promotion decision was made. 